\title{
POLA AKTIVITAS ENZIM PENCERNAAN LARVA IKAN KERAPU MACAN (Epinephelus fuscogutattus Forsskal, 1775)
}

\author{
Regina Melianawati* dan Rarastoeti Pratiwi**) \\ *) Balai Besar Riset Perikanan Budidaya Laut \\ Jl. Br. Gondol, Kec. Gerokgak, Kab. Buleleng, Kotak Pos 140, Singaraja-Bali 81101 \\ E-mail: regina_melnawati@yahoo.com \\ **) Fakultas Biologi, Universitas Gadjah Mada \\ Jl. Bulak Sumur, Jogjakarta 55281
}

(Naskah diterima: 8 April 2010; Disetujui publikasi: 21 Maret 2011)

\begin{abstract}
ABSTRAK
Masalah utama yang masih dihadapi dalam usaha budidaya ikan kerapu macan adalah tingkat mortalitas yang tinggi pada stadia larva. Perkembangan struktur sistem pencernaan dan fungsi enzimatik yang masih sederhana dan belum sempurna diyakini merupakan salah satu penyebab terjadinya hal tersebut. Penelitian ini bertujuan untuk (1) mendeteksi waktu awal aktivitas enzim pencernaan dan (2) mengetahui pola aktivitas enzim pencernaan pada larva umur 1 hingga 20 hari. Enzim yang dianalisis meliputi protease, amilase, dan lipase. Penelitian dilaksanakan dengan melakukan pengamatan secara berkesinambungan terhadap perkembangan yang terjadi secara alami pada larva selama periode waktu tertentu. Larva dipelihara di dalam hatcheri. Pakan yang diberikan kepada larva meliputi pakan alami rotifer Brachionus rotundiformis dan pakan buatan. Pengambilan sampel larva dilakukan pada larva umur 1, 2, 3, 5, 8, $11,14,17$, dan 20 hari. Variabel yang diamati meliputi: aktivitas enzim, jumlah pakan alami pada saluran pencernaan larva dan histologis larva. Data hasil pengukuran dianalisis secara deskriptif kuantitatif dan ditampilkan dalam bentuk grafik. Hasil penelitian menunjukkan bahwa (1) aktivitas amilase dan lipase mulai terdeteksi pada larva umur 1 hari, sedangkan protease mulai terdeteksi pada larva umur 2 hari, (2) pada larva umur 1 hingga 20 hari, pola aktivitas protease dan amilase menunjukkan peningkatan dari larva umur 1 hingga 11 hari, dan kemudian cenderung menurun, sedangkan pola aktivitas lipase menunjukkan penurunan dari larva umur 1 hingga 8 hari, kemudian cenderung meningkat. Aktivitas protease dan amilase yang tertinggi selama periode waktu tersebut terjadi pada larva umur 11 hari, sedangkan aktivitas lipase yang tertinggi pada larva umur 17 hari.
\end{abstract}

KATA KUNCl: enzim pencernaan, protease, amilase, lipase, larva, kerapu macan

ABSTRACT: The pattern of digestive enzyme activity of tiger grouper larvae (Epinephelus fuscogutattus Forsskal, 1775). By: Regina Melianawati and Rarastoeti Pratiwi

High mortality in larval stage is the main problem usually faced by fish farmers in tiger grouper culture. Poor development of digestive system structure and enzymatic function were suggested as the main problems. The objectives of this research were (1) to know the initial time of digestive enzyme of tiger grouper larvae could be detected and (2) to find out the digestive enzyme pattern of 1-20 days old larvae. Enzymes analyzed were protease, amylase and lipase. The experiment was done by continuous observation on the natural development of the larvae in a certain period. 
Larvae were reared in hatchery, fed with rotifer and artificial feed. Samples of larvae were 1, 2, 3, 5, 8, 11, 14, 17, and 20 days old larvae. Investigated variables included enzyme activity, number of live feed consumed by larvae and larval histology. Data were analyzed descriptively and presented in figures. Results of the experiment indicated that amylase and lipase activities have been early detected at 1 day old larvae, while protease activity was at 2 days old larvae. Protease and amylase activities pattern of 1-20 days old larvae increased from 1 until 11 days old larvae and then tended to decrease forward. While lipase activity pattern decreased from 1 until 8 days old larvae and then tended to increase afterward. The highest protease and amylase activities were found on 11 days old larvae, while the highest lipase activity was observed on 17 days old larvae.

\section{KEYWORDS: digestive enzyme, protease, amylase, lipase, tiger grouper, larvae}

\section{PENDAHULUAN}

Ikan kerapu macan (Epinephelus fuscoguttatus) merupakan salah satu jenis komoditas perikanan laut yang bernilai ekonomis tinggi. Penangkapan terhadap jenis ikan tersebut terus meningkat seiring dengan semakin tingginya permintaan pasar. Untuk menjaga kelestariannya di alam, maka kegiatan budidaya terhadap jenis ikan kerapu tersebut penting untuk dilaksanakan.

Namun demikian hingga saat ini usaha untuk memproduksi benih kerapu macan secara massal di panti benih masih menghadapi kendala berupa produksi benih belum berkesinambungan dan sintasan yang masih rendah. Dari hasil pengamatan, sekitar $60 \%$ kegagalan dalam produksi benih terjadi akibat kematian pada stadia larva (Komarudin et al., 1998). Belum sempurnanya pertumbuhan larva, khususnya pada sistem pencernaan, diyakini menjadi salah satu penyebab terjadinya hal tersebut.

Perkembangan struktur pencernaan akan diikuti pula oleh perkembangan enzim pencernaan (Handayani, 2006). Sistem pencernaan dan fungsi enzimatik pencernaan pada stadia larva masih sangat sederhana dan belum berkembang secara sempurna. Struktur sistem pencernaan yang masih sederhana pada larva diyakini berkorelasi pula dengan rendahnya produksi enzim pencernaan (Dabrowski \& Glogowski, 1977). Pada saat larva mulai mengkonsumsi pakan eksogennya, saluran pencernaan larva telah berisi enzim yang berkaitan dengan proses pencernaan dan penyerapan molekul protein, glikogen, dan lemak (Kolkovski, 2001). Dengan demikian, aktivitas enzim pencernaan merupakan suatu indikator yang baik untuk menentukan kapasitas pencernaan, pada saat aktivitas enzim tinggi dapat diindikasikan bahwa secara fisiologis larva telah mampu untuk memproses pakan eksogen (Gawlicka et al., 2000). Keberadaan enzim pencernaan yang meliputi protease, amilase, dan lipase merupakan indikator biologis terhadap kemampuan larva untuk mencerna pakan eksogen yang mengandung protein, karbohidrat dan lemak.

Penelitian ini bertujuan untuk mengetahui pola aktivitas enzim pencernaan pada larva ikan kerapu macan umur 1 hingga 20 hari. Pengetahuan mengenai pola aktivitas enzim pencernaan tersebut diharapkan dapat digunakan dalam penentuan waktu pemberian pakan eksogen dan jenis pakan eksogen yang sesuai dengan aktivitas enzim pencernaan sehingga diharapkan dapat meningkatkan efektivitas pemanfaatan pakan eksogen.

\section{BAHAN DAN METODE}

Penelitian dilaksanakan di Balai Besar Riset Perikanan Budidaya Laut (BBRPBL), Bali. Penelitian dilaksanakan dengan melakukan pengamatan secara berkesinambungan terhadap perkembangan yang terjadi secara alami pada larva selama periode waktu tertentu.

Pemeliharaan larva dilakukan pada 6 buah bak beton yang masing-masing berkapasitas maksimum $10 \mathrm{~m}^{3}$, berbentuk persegi panjang dan dilengkapi dengan sistem aerasi serta terletak di dalam ruang hatchery semi outdoor. Telur yang digunakan untuk penelitian ini adalah telur yang fertil dan berasal dari hasil pemijahan induk kerapu macan yang telah didomestikasi dalam tangki pemeliharaan di BBRPBL. Mulai hari ke-2 pagi, kedalam tangki pemeliharaan larva diberikan fitoplankton Nannochloropsis ocullata. Pakan alami berupa 
zooplankton rotifer Brachionus rotundiformis mulai diberikan pada hari ke-2 sore dengan kepadatan awal 5-10 ind./mL. Pakan buatan mulai diberikan pada hari ke-11 siang. Untuk menjaga kualitas air di dalam media pemeliharaan, dilakukan pergantian air dan penyiphonan, yang dilakukan secara periodik, selama periode pemeliharaan larva berlangsung, mulai larva umur 10 hari.

Pengambilan sampel dilakukan pada larva umur 1, 2, 3, 5, 8, 11, 14, 17, dan 20 hari. Jumlah sampel yang digunakan untuk analisis aktivitas enzim sebanyak 80-500 larva, tergantung pada umur dan ukuran tubuh larva. Sampel ini kemudian disimpan pada temperatur $-80^{\circ} \mathrm{C}$ hingga dilaksanakan analisis. Disamping itu, 10 sampel larva dibedah untuk dihitung jumlah pakan alami dalam pencernaannya serta 10-15 sampel larva difiksasi untuk kajian histologis.

Analisis enzim didahului dengan melakukan ekstraksi terhadap sampel. Proses ekstraksi berlangsung pada kondisi dingin yaitu dengan cara menempatkan tabung eppendof yang berisi sampel di dalam kotak es. Ekstraksi sampel dilakukan dengan cara menggerus sampel hingga hancur, kemudian menambahkan aquabidest dingin sebanyak $1500 \mu \mathrm{L}$. Selanjutnya sampel disentrifuse dengan kecepatan $8000 \mathrm{rpm}$ pada suhu $4^{\circ} \mathrm{C}$ selama 5 menit. Bagian supernatan dari hasil sentrifuse tersebut kemudian diambil sebanyak $1.500 \mu \mathrm{L}$ dan ditempatkan kedalam tabung eppendof volume $2 \mathrm{~mL}$ yang baru. Bagian inilah yang kemudian digunakan untuk analisis aktivitas enzim. Analisis dilakukan secara duplo.

Aktivitas protease dan amilase dianalisis menurut metode Bergmeyer et al. (1983) yang telah dimodifikasi, sedangkan aktivitas enzim lipase dianalisis menurut metode Linfield et al. (1984) yang telah dimodifikasi (Ekowati Chasanah, peneliti Balai Besar Riset Pengolahan Produk dan Sosial Ekonomi Kelautan dan Perikanan, 2008, komunikasi pribadi). Aktivitas protease menggunakan casein sebagai substrat dan tyrosin sebagai standar, aktivitas amilase dengan starch sebagai substrat dan maltosa sebagai standar, sedangkan aktivitas lipase menggunakan minyak kedelai sebagai substrat.

Penghitungan jumlah pakan dalam pencernaan dilakukan dengan mengambil sampel larva secara periodik kemudian diamati dengan mikroskop, dibedah bagian pencernaannya dan dihitung jumlah pakan alami yang terdapat di dalamnya.

Pengamatan histologis dilakukan dengan cara mengambil sampel larva secara periodik kemudian sampel difiksasi dalam larutan ethanol $70 \%$ hingga saat pembuatan preparat histologis yang meliputi dehidrasi, clearing, infiltrasi, embedding, sectioning, peletakan pada object glass, staining dan mounting, selanjutnya diamati dengan mikroskop (Istriyati, 2005).

Variabel yang diamati dalam penelitian ini meliputi (1) variabel bebas: umur larva dan jumlah pakan dalam organ pencernaan larva dan (2) variabel tergantung: aktivitas enzim pencernaan yang terdiri atas protease, amilase, dan lipase. Di samping itu juga dilakukan pengamatan histologis yang dibuat secara serial untuk mengetahui perkembangan sistem pencernaan larva.

Data yang diperoleh dari hasil pengukuran dianalisis secara deskriptif kuantitatif dan ditampilkan dalam bentuk grafik histogram antara umur dengan variabel pengamatan. Hasil pengamatan histologis dianalisis secara deskriptif.

\section{HASIL DAN BAHASAN}

\section{Aktivitas Enzim}

Hasil pengamatan memperlihatkan bahwa aktivitas amilase dan lipase sudah mulai terdeteksi pada larva umur 1 hari, masingmasing $0,168 \pm 0,100$ unit/larva dan $0,822 \pm 0,700$ unit/larva, sedangkan aktivitas protease baru mulai terdeteksi pada larva umur 2 hari, yaitu 0,0004 $\pm 0,0002$ unit/larva. Pada larva umur 2 hari aktivitas amilase meningkat menjadi 0,214 $\pm 0,020$ unit/larva dan lipase menjadi 0,829 $\pm 0,328$ unit/larva (Gambar 1). Terdeteksinya aktivitas enzim pada larva umur tersebut menunjukkan telah berlangsungnya proses hidrolisis pakan, dalam hal ini adalah pakan endogen yang berupa kuning telur dan butir minyak. Kuning telur banyak mengandung protein, sedangkan butir minyak banyak mengandung lemak. Oleh karenanya aktivitas protease dan lipase terdeteksi cukup tinggi pada larva umur 2 hari.

Terdeteksinya aktivitas enzim sebelum larva mulai mengkonsumsi pakan eksogen menunjukkan bahwa aktivitas enzim pada larva tersebut tidak dipengaruhi oleh induksi pakan. 

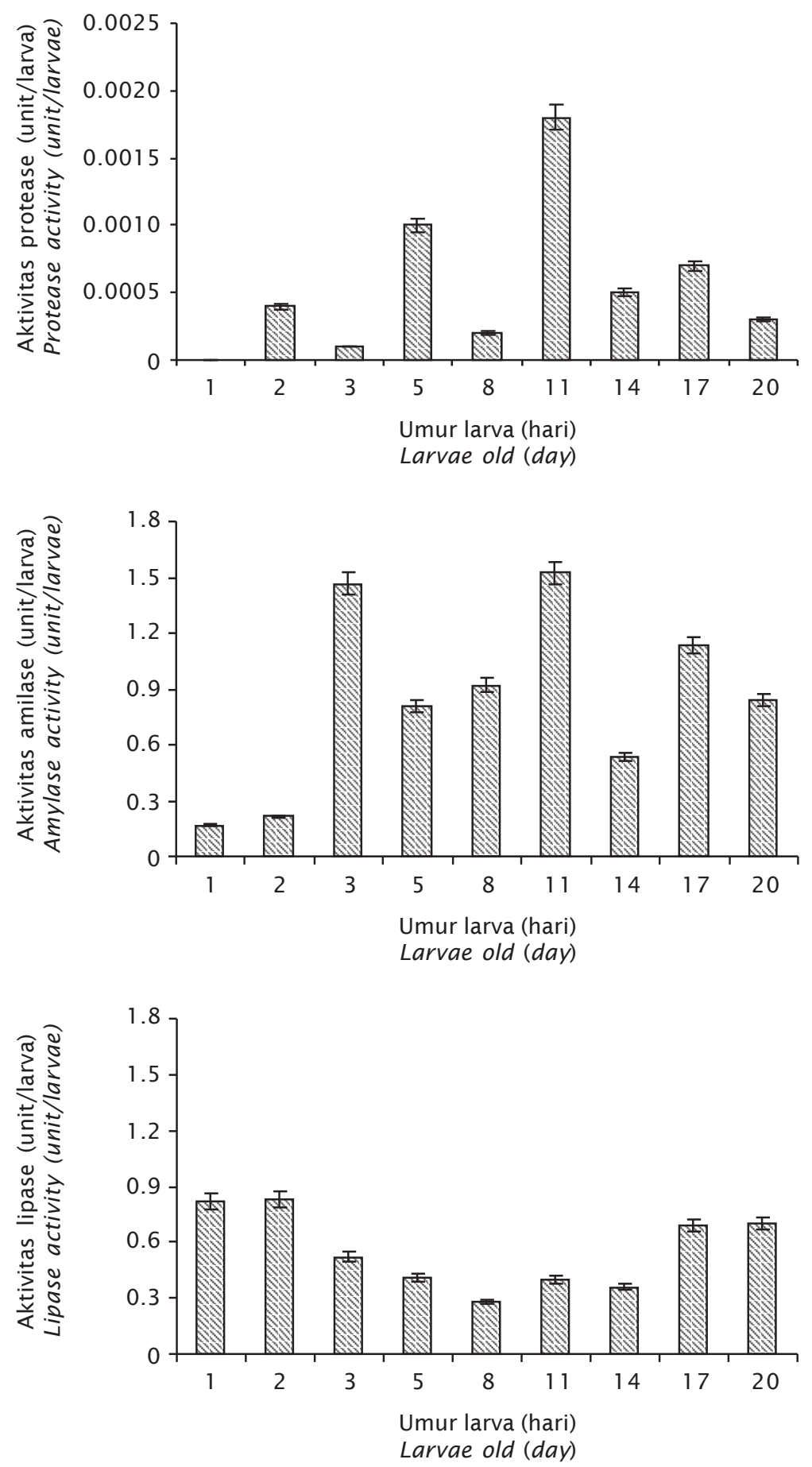

Gambar 1. Aktivitas protease (A), amilase (B) dan lipase (C) larva ikan kerapu macan umur 1-20 hari

Figure 1. Activity of protease (A), amylase (B) and lipase (C) of 1-20 days old tiger grouper larvae 
Aktivitas enzim yang terdeteksi sebelum larva mulai mengkonsumsi pakan eksogen juga terjadi pada larva ikan kerapu lumpur (Epinephelus coioides) yaitu pada larva umur 2 hari (Eusebio et al., 2004; McBride, 2004). Dengan teknik histokimia, terlihat bahwa aktivitas enzim pada larva ikan kerapu lumpur (E. coioides) sudah terdeteksi selama larva masih tergantung pada pakan endogennya dan maltase mulai terdeteksi lemah pada larva umur 2 hari (Quinito et al., 2004). Aktivitas protease pada larva ikan kerapu batik $(E$. microdon) juga mulai terdeteksi pada larva umur 1 hari (Jayadi, 2004). Pada larva ikan baung (Mystus nemurus) aktivitas protease dan lipase juga telah terdeteksi pada larva umur 2 hari (Suryanti, 2002).

Namun pada beberapa jenis larva, aktivitas enzimnya baru terlihat pada saat larva mulai mengkonsumsi pakan eksogen, seperti pada larva African catfish (Clarias gariepinus) (Segner \& Verreth, 1995). Aktivitas protease, amilase, dan lipase mulai terdeteksi pada larva ikan kerapu bebek (Cromileptes altivelis) umur 4 hari yang berarti bahwa pada saat itu larva sudah mengkonsumsi pakan eksogen (McBride, 2004). Dengan teknik in situ hybridization, terlihat bahwa trypsin, chymotrypsin dan lipase mulai terekspresi keberadaannya di pankreas larva ikan Japanese flounder (Paralichthys olivaceus) yang sudah mengkonsumsi pakan eksogen pada umur 3 hari (Srivastava et al., 2002).

Aktivitas protease dan lipase pada larva umur 3 hari cenderung menurun dibandingkan dengan hari sebelumnya. Penurunan aktivitas ini diduga karena pakan eksogen yang diberikan memiliki struktur yang berbeda dengan yang ada pada tubuh larva sehingga proses hidrolisis berjalan lambat dan mengakibatkan aktivitas enzim yang terdeteksi rendah. Sebaliknya aktivitas amilase pada larva umur 3 hari meningkat. Hal ini menunjukkan bahwa proses hidrolisis karbohidrat lebih aktif daripada hidrolisis protein dan lemak. Struktur molekul karbohidrat pakan yang diberikan lebih sederhana dan tidak adanya struktur yang spesifik, memungkinkan proses hidrolisis yang dilakukan amilase dapat berlangsung cepat.

Pada larva umur 5-11 hari terlihat bahwa aktivitas enzim cenderung meningkat dengan semakin meningkatnya umur larva. Aktivitas protease mengalami peningkatan, dari $0,0001 \pm 0,0$ unit/larva pada larva umur 5 hari, menjadi 0,0002 $\pm 0,0001$ unit/larva pada larva umur 8 hari, kemudian menjadi 0,001 8 $\pm 0,0004$ unit/larva pada larva umur 11 hari. Aktivitas amilase pada larva umur 5 hari $0,813 \pm 0,112$ unit/larva, meningkat menjadi 0,921 $\pm 0,362$ unit/larva pada larva umur 8 hari dan meningkat lagi menjadi 1,522 $\pm 0,142$ unit/larva pada larva umur 11 hari. Aktivitas lipase mengalami penurunan, dari $0,412 \pm 0,054$ unit/larva pada larva umur 5 hari, menjadi $0,278 \pm 0,078$ unit/ larva pada larva umur 8 hari, kemudian meningkat menjadi 0,398 $\pm 0,021$ unit/larva pada larva umur 11 hari.

Kecenderungan peningkatan aktivitas enzim dapat disebabkan karena beberapa hal. Pertama, semakin besarnya ukuran tubuh larva, diikuti pula dengan semakin meningkatnya jumlah jaringan penyusun tubuh, termasuk didalamnya adalah jaringan penghasil enzim, sehingga akan meningkatkan aktivitas enzim. Kedua, semakin besar umurnya, larva akan semakin banyak mengkonsumsi pakan eksogen yang merupakan substrat bagi enzim sehingga akan menstimulir peningkatan aktivitas enzim. Pendapat serupa dikemukakan oleh Ferraris et al. (1987) yang menyatakan bahwa peningkatan aktivitas protease disebabkan oleh meningkatnya jaringan penghasil enzim dan Jayadi (2004) yang menyatakan bahwa peningkatan konsumsi pakan akan meningkatkan kuantitas pakan yang berperan sebagai substrat yang akan dihidrolisis oleh enzim yang ada.

Pada larva umur 14 hari aktivitas protease $0,00054 \pm 0,00009$ unit/larva, kemudian meningkat menjadi $0,00073 \pm 0,00008$ unit/ larva pada larva umur 17 hari dan turun menjadi $0,00030 \pm 0,00005$ unit/larva pada larva umur 20 hari. Aktivitas amilase pada larva umur 14, 17, dan 20 hari, berturut-turut adalah $0,531 \pm 0,003$ unit/larva, $1,135 \pm 0,092$ unit/ larva dan 0,839 $\pm 0,049$ unit/larva. Aktivitas lipase pada larva umur 14, 17, dan 20 hari, berturut-turut adalah $0,358 \pm 0,043$ unit/larva, $0,689 \pm 0,023$ unit/larva dan $0,700 \pm 0,048$ unit/ larva. Hasil tersebut menunjukkan bahwa aktivitas ketiga jenis enzim pada larva umur 17 hari cenderung lebih tinggi dibandingkan aktivitasnya pada larva umur 14 hari, namun pada larva umur 20 hari aktivitasnya menurun.

Aktivitas enzim yang cenderung menjadi lebih rendah setelah diberi pakan buatan pada umur 11 hari, menunjukkan masih rendahnya kemampuan larva dalam menghidrolisis pakan buatan. Hal ini juga mengindikasikan bahwa 
jumlah pakan buatan yang dapat dimanfaatkan oleh larva masih terbatas. Oleh karenanya, pada aplikasi dalam usaha budidaya, pemberian pakan buatan pada larva berumur 14-20 hari masih harus dibatasi jumlahnya dan disesuaikan dengan kebutuhan larva sehingga pakan buatan yang diberikan dapat dimanfaatkan secara efektif dan efisien oleh larva. Larva mungkin saja menelan pakan buatan yang diberikan, namun apabila belum dapat mencernanya maka larva akan mati dengan saluran pencernaan yang penuh berisi pakan (Cahu \& Infante, 2001).

Secara keseluruhan pola aktivitas protease dan amilase menunjukkan peningkatan mulai dari larva umur 1 hingga 11 hari, namun kemudian cenderung menurun. Sebaliknya, pola aktivitas lipase menunjukkan penurunan mulai dari larva umur 1 hingga 8 hari, kemudian cenderung meningkat.

Pada larva ikan kerapu lumpur dan kerapu bebek, aktivitas protease, amilase, dan lipase, masing-masing mulai terdeteksi pada larva umur 2 dan 4 hari dan aktivitas tersebut semakin meningkat dengan semakin meningkatnya umur larva (Eusebio et al., 2004; McBride, 2004). Aktivitas protease pada larva ikan kerapu batik (E. microdon) semakin meningkat hingga larva berumur 35 hari (Jayadi, 2004). Aktivitas tripsin pada larva ikan kerapu bebek juga meningkat dengan semakin meningkatnya umur larva (Tridjoko et al., 2002).

Dengan teknik histokimia, terlihat bahwa aktivitas maltase pada larva ikan kerapu lumpur (E. coioides) terekspresi semakin kuat mulai larva umur 14 hari, sedangkan lipase justru mulai terdeteksi lemah pada larva umur 14 hari dan terdeteksi semakin kuat pada larva umur 25 hari (Quinito et al., 2004). Pada larva ikan patin (Pangasius hypophthalmus), aktivitas protease menurun pada larva umur 3 hari kemudian meningkat hingga larva umur 7 hari dan kemudian menurun kembali hingga larva umur 15 hari. Aktivitas protease tertinggi terjadi pada larva umur 7 hari. Aktivitas amilase meningkat tajam pada larva umur 2 hari, kemudian menurun hingga larva umur 5 hari, kemudian meningkat lagi pada larva umur 7 hari dan menurun lagi pada larva umur 15 hari. Aktivitas lipase meningkat mulai larva umur 1 hari hingga 5 hari, kemudian menurun hingga larva umur 15 hari. Aktivitas lipase tertinggi terjadi pada larva umur 5 hari (Augustine, 2003). Aktivitas protease pada larva ikan lele dumbo (Clarias sp.) yang dipelihara di dalam ruangan, meningkat mulai dari larva umur 1 hingga 7 hari kemudian menurun hingga larva umur 10 hari dan meningkat lagi hingga larva umur 15 hari. Aktivitas protease tertinggi terjadi pada larva umur 7 hari. Aktivitas amilase dan lipase pada larva yang dipelihara dengan sistem yang sama, meningkat, masing-masing mulai larva umur 1 hingga 5 dan 7 hari, kemudian menurun (Kuncoro, 2006). Aktivitas enzim pencernaan larva ikan betutu (Oxyeleotris marmorata) yang dipelihara dalam ruang dengan cahaya normal, menunjukkan peningkatan dari larva umur 2 hingga 17 hari, kemudian menurun hingga larva umur 22 hari dan meningkat lagi hingga larva umur 32 hari. Aktivitas protease tertinggi terjadi pada larva umur 17 hari. Aktivitas amilase meningkat dari larva umur 2 hingga 12 hari, kemudian menurun hingga larva umur 2 hari, kemudian meningkat dan menurun lagi hingga larva berumur 32 hari. Aktivitas amilase tertinggi terjadi pada larva umur 12 hari. Aktivitas lipase sangat berfluktuasi sejak larva umur 2 hingga 32 hari. Aktivitas lipase tertinggi terjadi pada larva umur 7 hari (Effendi, 1995).

Aktivitas protease pada larva ikan gurami (Osphronemus goramy) umur 10 hingga 46 hari yang berukuran 2,4 cm, menunjukkan adanya peningkatan, sedangkan pada benih yang berukuran 6,59 sampai dengan 13,97 cm aktivitasnya menurun. Aktivitas amilase dan lipase juga meningkat sejalan dengan meningkatnya umur/ukuran ikan (Affandi et al., 1994).

Dalam penelitian ini, aktivitas protease dan amilase yang tertinggi adalah pada larva umur 11 hari, sedangkan aktivitas lipase yang tertinggi pada larva umur 17 hari. Apabila dikaitkan dengan jumlah rotifer yang terdapat di dalam saluran pencernaan larva, jumlah rotifer pada larva umur 11 hari tersebut tidak jauh berbeda dengan jumlah rotifer pada larva kerapu macan umur 8 hari (Gambar 2). Pada larva umur 8 dan 11 hari terdapat rotifer, masing-masing sebanyak 40,44 $\pm 19,89$ dan $45,29 \pm 22,80$ individu. Meskipun jumlah pakan yang dihidrolisis hampir sama namun aktivitas enzim pada kedua umur larva tersebut terlihat sangat berbeda. Perbedaan yang paling menyolok terlihat pada protease. Aktivitas protease pada larva umur 8 hari $0,0002 \pm 0,0001$ unit/larva kemudian menjadi $0,0018 \pm 0,0004$ unit/larva pada larva umur 11 hari. Peningkatan aktivitas amilase tertinggi, dari 0,921 10,362 
unit/larva pada larva umur 8 hari menjadi $1,522 \pm 0,142$ unit/larva pada larva umur 11 hari. Sedangkan peningkatan aktivitas lipase tertinggi, dari 0,513 $\pm 0,071$ unit/larva pada larva umur 14 hari menjadi 0,993 $\pm 0,0120$ unit/ larva pada larva umur 17 hari. Aktivitas enzim yang tinggi pada larva umur tersebut diduga merupakan hasil sekresi dari larva itu sendiri. Dengan demikian, pada saat itu larva diindikasikan sudah mampu untuk memproses pakan eksogen dengan enzim yang disekresikannya sendiri. Gawlicka et al. (2000) mengemukakan bahwa pada saat aktivitas enzim tinggi dapat diindikasikan bahwa secara fisiologis larva telah mampu untuk memproses pakan eksogen. Pakan yang dimaksud disini adalah pakan buatan. Jadi pemberian pakan buatan bagi larva ikan kerapu macan, yang dikaitkan dengan aktivitas enzim pencernaannya, adalah pada larva yang berumur 11 hari.

Waktu pemberian pakan buatan yang disesuaikan dengan aktivitas enzimatis ikan, bagi benih ikan gurame adalah setelah benih berukuran lebih dari 2,4 cm (Affandi et al., 1994), bagi benih ikan botia (Botia macracantha) dilakukan mulai benih ukuran 1,5 inchi (Suryanti et al., 2006), sedangkan bagi larva ikan baung mulai umur 13 hari (Suryanti, 2002) dan bagi benih ikan baung pada umur 19 hari (Suryanti \& Priyadi, 2002). Dengan demikian, bagi jenis ikan tersebut, pakan buatan nampaknya hanya dapat dimanfaatkan pada fase yuwana, yaitu larva yang telah mengalami metamorfosis dan bukan oleh larva karena pada fase tersebut perkembangan pankreas dan kelenjar pencernaannya telah lengkap (Beccaria et al., 1991).

Hasil pengamatan terhadap jumlah rotifer yang terdapat dalam pencernaan larva menunjukkan kecenderungan peningkatan seiring dengan meningkatnya umur larva (Gambar 2). Pada larva umur 3 dan 5 hari terdapat $6,30 \pm 0,02$ dan $12,05 \pm 8,66$ individu rotifer, pada larva umur 8 dan 11 hari, masingmasing terdapat sebanyak 40,44 $\pm 19,89$ dan $45,29 \pm 22,80$ individu rotifer. Sedangkan pada larva umur 14, 17, dan 20 hari terdapat $62,36 \pm 29,61 ; 74,31 \pm 26,44$; dan $96,90 \pm 51,27$ individu rotifer.

\section{Histologis Larva}

Pengamatan histologis menunjukkan bahwa pada larva umur 1 dan 2 hari masih memiliki kuning telur (Gambar 3A, 3B). Butir minyak sebenarnya juga dimiliki oleh larva umur tersebut, namun keberadaannya tidak terdeteksi secara histologis. Hal ini mungkin disebabkan telah mengalami kerusakan selama dalam proses pengerjaan analisis tersebut. Saluran pencernaan larva masih berupa tabung yang lurus dan membengkok pada bagian bawahnya. Pada larva umur 3 hari, kuning telur sudah tidak terdeteksi lagi, saluran pen-

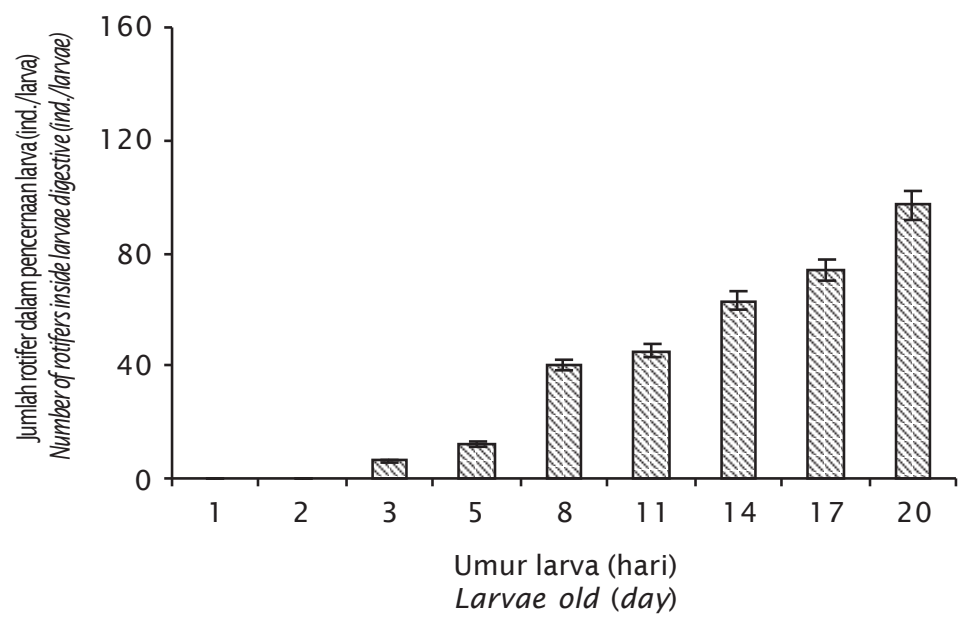

Gambar 2. Jumlah rotifer dalam saluran pencernaan larva ikan kerapu macan umur 1-20 hari

Figure 2. Number of rotifers inside digestive tract of 1-20 days old tiger grouper larvae 


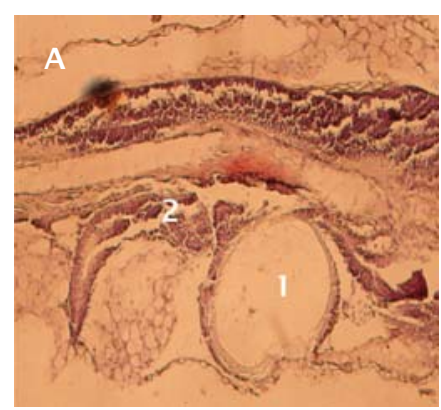

$\overline{1 \mu \mathrm{m}}$

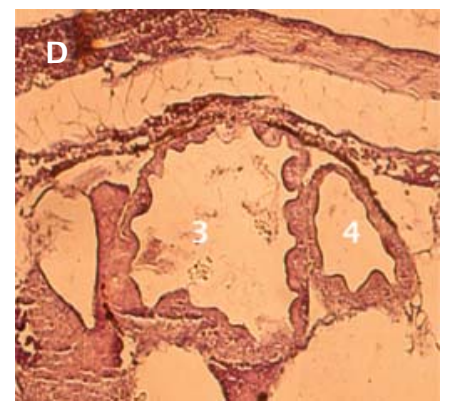

$\overline{1 \mu \mathrm{m}}$

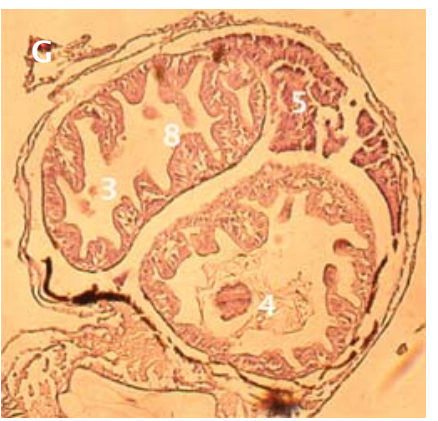

$1 \mu \mathrm{m}$

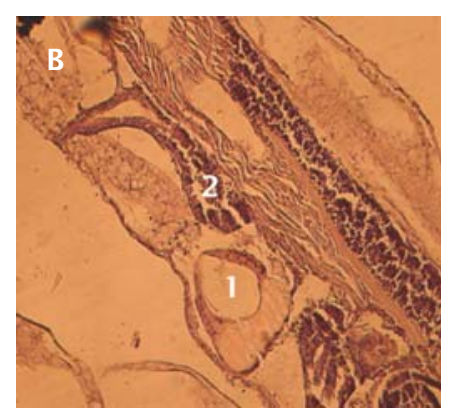

$\overline{1 \mu \mathrm{m}}$

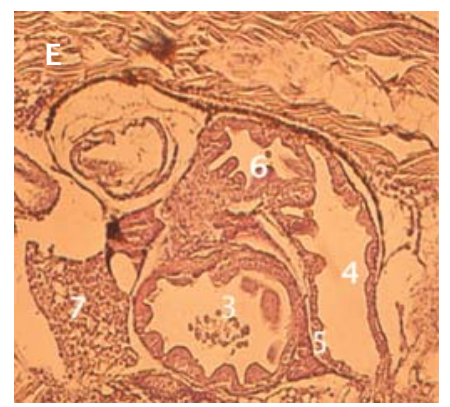

$\overline{1 \mu \mathrm{m}}$

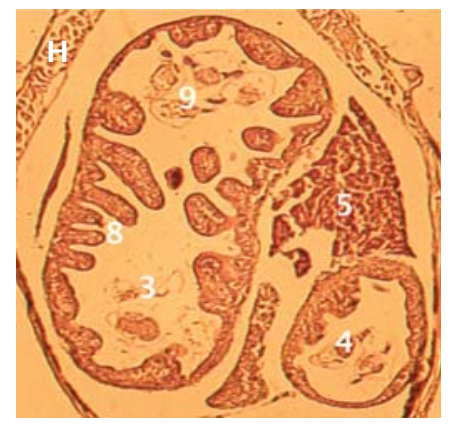

$1 \mu \mathrm{m}$

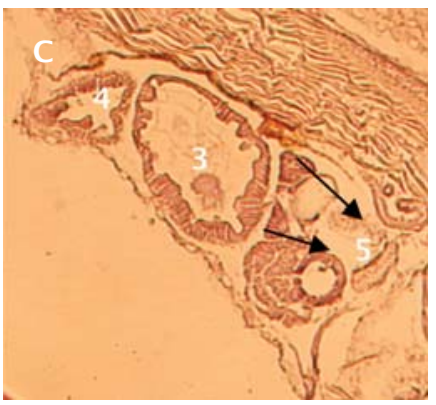

$\overline{1} \mu \mathrm{m} \quad$ Perbesaran 100x

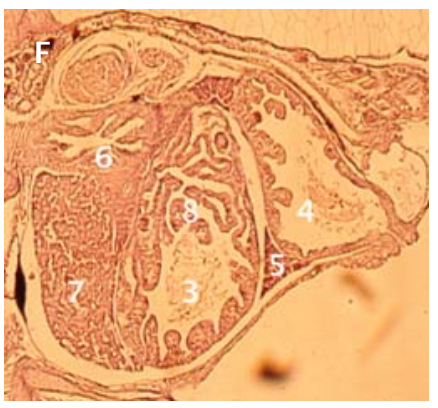

$\overline{1 \mu \mathrm{m}} \quad$ Perbesaran 200x

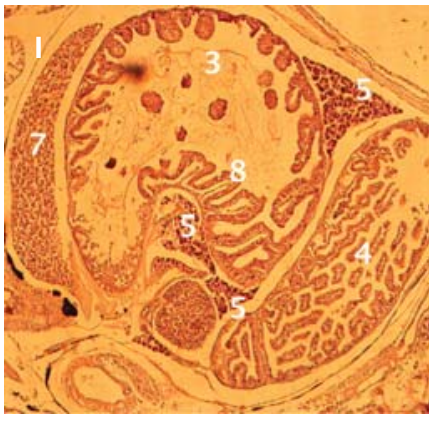

$1 \mu \mathrm{m} \quad$ Perbesaran 100x

Gambar 3. Histologis larva ikan kerapu macan umur 1 hari (A), 2 hari (B), 3 hari (C), 5 hari (D), 8 hari (E), 11 hari $(\mathrm{F}), 14$ hari $(\mathrm{C}), 17$ hari $(\mathrm{H})$, dan 20 hari (I). 1: kuning telur, 2: saluran pencernaan, 3: intestine, 4: rektum, 5: pankreas. 6: esophagus, 7: liver, 8: villi, 9: rotifer yang dikonsumsi

Pewarnaan haemotoxylen-eosin

Figure 3. Histology of tiger grouper larve 1 day old ( $A$ ), 2 days old (B), 3 days old (C), 5 days old (D), 8 days old $(E), 11$ days old, $(F), 14$ days old $(G), 17$ days old and 20 days old $(I), 1$ : yolk sac, 2: digestive tract, 3: intestine, 4:rectum, 5: pancreas, 6: esophagus, 7: liver, 8: villi, 9: rotifers consumed

Haemotoxylen-eosin Staining 
cernaan menjadi lebih besar dan telah mengalami diferensiasi menjadi intestine dan rektum, villi masih rendah serta mulai terdeteksinya pankreas (Gambar 3C). Pankreas merupakan organ pencernaan penting pada stadia awal larva sebelum terbentuknya lambung (Kurokawa \& Suzuki, 1996).

Pada larva umur 1 hingga 3 hari belum terbentuk lambung, sehingga fungsi lambung sebagai penampung pakan yang dikonsumsi larva, digantikan oleh intestine depan. Hasil proses organogenesis berupa semakin besarnya ukuran saluran pencernaan, terdeteksinya pankreas dan terdiferensiasinya saluran pencernaan, menunjukkan bahwa larva telah siap untuk mencerna pakan eksogen pada umur 3 hari. Namun demikian, saluran pencernaan larva yang masih sangat sederhana, lambung yang belum terbentuk, intestine yang masih pendek dan bagian permukaan dalamnya yang relatif belum berlekuk-lekuk, menandakan masih rendahnya produksi enzim (Effendi, 1995).

Pada pengamatan histologis larva umur 5 hari terlihat ruang intestine dan rektum yang lebih besar dibandingkan pada larva umur 3 hari (Gambar 3D). Pada larva umur 8 hari sudah terlihat adanya esophagus dan liver (Gambar 3E). Pankreas sebenarnya sudah terdeteksi sejak larva umur 3 hari, namun pada larva umur 5 hari tersebut keberadaan pankreas tidak terdeteksi. Hal ini mungkin disebabkan karena posisi larva yang kurang tepat pada proses sectioning atau pada saat peletakan pita hasil sectioning pada obyek glass. Pada larva umur 11 hari terlihat semakin besarnya intestine dan rektum dan semakin tingginya villi (Gambar 3F). Hal tersebut menunjukkan bahwa kapasitas proses pencernaan dan penyerapan pakan sudah semakin meningkat.

Pada larva umur 14, 17, dan 20 hari, terlihat bahwa struktur pencernaan larva sudah semakin berkembang dan menjadi lebih kompleks. Semakin meningkat umur larva diikuti pula dengan semakin besarnya liver, intestine dan rektum serta semakin tersebarnya pankreas dan semakin tingginya villi (Gambar 3G, 3H, 3I). Keberadaan mikrovili merupakan upaya untuk memperluas daerah penyerapan, sehingga ukuran mikrovilli akan berpengaruh terhadap proses penyerapan. Mikrovili yang panjang akan lebih cepat menyerap pakan dibandingkan dengan mikrovili yang pendek (Audesirk \& Audesirk, 1999; Kuperman \& Kuz'mina, 1994; Lewis,
1998; Purves et al., 1992; Starr \& Taggart, 1995).

Dengan semakin sempurnanya proses organogenesis sistem pencernaan, menunjukkan adanya peningkatan kapasitas pencernaan larva. Larva telah mampu menampung lebih banyak jumlah pakan, mensekresikan lebih banyak enzim pencernaan dan sekaligus mencerna lebih banyak pakan. Hal ini sekaligus juga menunjukkan bahwa larva telah mampu menghidrolisis seluruh jenis pakan yang diberikan dalam penelitian ini.

\section{KESIMPULAN}

- Aktivitas amilase dan lipase mulai terdeteksi pada larva umur 1 hari, sedangkan aktivitas protease mulai terdeteksi pada larva umur 2 hari.

- Pada larva umur 1 hingga 20 hari pola aktivitas protease dan amilase menunjukkan peningkatan mulai dari larva umur 1 hingga 11 hari dan kemudian cenderung menurun, sedangkan pola aktivitas lipase menunjukkan penurunan mulai dari larva umur 1 hingga 8 hari, kemudian cenderung meningkat.

- Aktivitas protease dan amilase tertinggi selama periode waktu tersebut terjadi pada larva umur 11 hari, sedangkan aktivitas lipase tertinggi terjadi pada larva umur 17 hari.

- Dalam aplikasi budidaya, pemberian pakan buatan dengan kandungan protein dan karbohidrat tinggi sebaiknya dilakukan mulai larva umur 11 hari, sedangkan pakan yang banyak mengandung lemak sebaiknya diberikan mulai larva umur 17 hari.

\section{UCAPAN TERIMA KASIH}

Ucapan terima kasih disampaikan kepada Badan Riset Kelautan dan Perikanan Departemen Kelautan dan Perikanan sebagai penyandang dana penelitian melalui anggaran riset Balai Besar Riset Perikanan Budidaya Laut Tahun Anggaran 2008. Ucapan terima kasih juga disampaikan kepada Dr. Ekowati Chasanah, peneliti Balai Besar Riset Pengolahan Produk dan Sosial Ekonomi Kelautan dan Perikanan, yang telah memberikan supervisi pada analisis enzim; serta kepada Dr. T. Kurokawa, staf peneliti National Research Institute for Aquaculture, yang telah mengoreksi hasil pengamatan histologis. 


\section{DAFTAR ACUAN}

Affandi, R., Mokoginta, I., \& Suprayudi, A. 1994. Perkembangan enzim pencernaan benih ikan gurame, Osphronemus goramy, Lacepede. Jurnal Ilmu-Ilmu Perairan dan Perikanan Indonesia, II(2): 63-71.

Audesirk, T. \& Audesirk, G. 1999. Nutritions and digestion. In: Biology, life on earth. $5^{\text {th }}$ edition. International edition. Prentice-Hall. USA, p. 570-59.

Augustine, D. 2003. Perkembangan enzim pencernaan larva ikan patin, Pangsius hypophthalmus. Program studi budidaya perairan. IPB, $60 \mathrm{hlm}$.

Beccaria, C., Diaz, J.P., Connes, R., \& Chatain, B. 1991. Organogenesis of the exocrine pancreas in the sea bass Dicentrarchus labrax L., reared extensively and intensively. Aquaculture, 99: 339-354.

Bergmeyer, H.U., Grossl, M., \& Walter, H.E. 1983. Reagents for enzymatic analysis. In: H.U. Bergmeyer (ed.) Methods in enzymatic analysis vol. II. $3^{\text {rd }}$ eds. Weinheim, p. 274-275.

Cahu, C. \& Infante, J.Z. 2001 . Substitution of live food by formulated diets in marine fish larvae. Aquaculture, 22: 161-180.

Dabrowski, K. \& Glogowski, J. 1977. Studies on the role of exogenous proteolytic enzymes in digestion processes in fish. Hydrobiologia, 54(2): 129-134.

Effendi, R. 1995. Perkembangan enzim pencernaan larva ikan betutu, Oxyeleotris marmorata (BLKR.), yang dipelihara pada cahaya normal dan teduh. Program Pascasarjana IPB, $89 \mathrm{hlm}$.

Eusebio, P.S., Toledo, J.D., Mamauag, R.E.P., \& Bernas, M.J.G. 2004. Digestive enzyme activity in developing grouper (Epinephelus coioides) larvae. In: Rimmer, M.A. et al. Advances in grouper aquaculture. Canberra, p. 35-40.

Ferraris, R.P., Tan, J.D., \& DelaCruz, M.C. 1987. Development of the digestive tract of milkfish Chanos chanos (Forskal): histology and hystochemistry. Aquaculture, 69: 379-386.

Gawlicka, Parent, A.B., Horn, M.H., Ross, N., Opstad, I., \& Torrissen, O.J. 2000. Activity of digestive enzyme in yolk sac larvae of atlantic halibut (Hippoglossus hippoglossus): indication of readiness for first feeding. Aquaculture, 184: 303-314.

Handayani, S. 2006. Studi efisiensi pemanfaatan karbohidrat pakan bagi pertumbuhan ikan gurame (Osphronemus gouramy Lac.) sejalan dengan perubahan enzim pencernaan dan insulin. Sekolah Pascasarjana IPB.

Hunter, J.R. 1980. The feeding behavior and ecology of marine fish larvae. In: Bardach, J.E. et al., 1980. Fish behavior and its use in the capture and culture of fishes. ICLARM, Manila, Philippines, p. 287-330.

Istriyati. 2005. Petunjuk praktis praktikum mikroteknik hewan. Laboratorium Histologi Fakultas Biologi Universitas Gadjah Mada, p. 6-8.

Jayadi. 2004. Aspek biologi dan fisiologi serta kebutuhan lingkungan dan larva ikan kerapu batik (Epinephelus microdon). Program Pascasarjana Universitas Hasanuddin. Makassar, $105 \mathrm{hlm}$.

Kolkovski, S. 2001. Digestive enzymes in fish larvae and yuwanaes-implications and applications to formulated diets. Aquaculture, 200: 181-201.

Komarudin, U., Prihaningrum, A., \& Arifin, Z. 1998. Pemeliharaan larva kerapu macan (Epinephelus fuscoguttatus) dengan multispesies zooplankton. Dalam Sudradjat et al. (eds). Seminar Teknologi Perikanan Pantai, hlm. 142-148.

Kuncoro, M.D. 2006. Perkembangan enzim pencernaan dan pertumbuhan larva ikan lele dumbo, Clarias sp., yang dipelihara dalam sistem pembenihan indoor dan outdoor. Program studi teknologi dan manajemen akuakultur. IPB, $41 \mathrm{hlm}$.

Kuperman, B.I. \& Kuz'mina, V.V. 1994. The ultrastructure of the intestinal epithelium in fishes with different types of feeding. J. Fish Biology, 41: 181-193.

Kurokawa, T. \& Suzuki, T. 1996. Formation of the diffuse pancreas and the development of digestive enzyme synthesis in larvae of the Japanese flounder Paralichthys olivaceus. Aquaculture, 141: 267-276.

Lewis, R. 1998. Digestion and nutrition. In: Life. $3^{\text {rd }}$ eds. McGraw-Hill, p. 749-768.

Linfield, W.M., Barangkas, R.A., Sivieri, L., Serota, S., \& Stevenson, R.W. 1984. Enzymatic fat and synthesis. JAOCS, 18(2): 78-87.

McBride, S. 2004. The activity of digestive enzymes in larval grouper and live feed. In: Rimmer, M.A. et al. Advances in grouper aquaculture. Canberra, p. 41-46.

Purves, W.K., Orians, G.H., \& Heller, H.C. 1992. Animal nutrition. In: Life: the science of biology. Sinauer Assc., p. 935-961. 
Quinitio, G.F., Sa-an, A.C., Toledo, J.D., \& Tan-Fermin, J.D. 2004. Localisation of enzymes in the digestive system during early development of the grouper (Epinephelus coioides). In: Rimmer, M.A. et al. Advances in grouper aquaculture. Canberra, p. 30-34.

Segner, H. \& Verreth, J. 1995. Metabolic enzyme activities in larvae of the African catfish, Clarias gariepinus: changes in relation to age and nutrition. Fish Physiology and Biochemistry, 14(5): 385-398.

Slamet, B. \& Tridjoko. 1997. Pengamatan pemijahan alami, perkembangan embrio dan larva ikan kerapu batik, Epinephelus microdon dalam bak terkontrol. J. Pen. Perik. Indonesia, III, (4): 40-50.

Srivastava, A.S., Kurokawa, T., \& Suzuki, T. 2002. mRNA expression of pancreatic enzyme precursors and estimation of protein digestibility in first feeding larvae of the Japanese flounder Paralichthys olivaceus. Comparative Biochemistry and Physiology, 132A: 629-635.

Starr, C. \& Taggart, R. 1995. Digestion and human nutrition. In: Biology, the unity and diversity of life. $7^{\text {th }}$ eds. Wadsworth Publishing, p. 714-730.
Suryanti, Y. 2002. Perkembangan aktivitas enzim pencernaan pada larva/benih ikan baung (Mystus nemurus C.V.). J. Pen. Perik. Indonesia, VIII(3): 15-18.

Suryanti, Y. \& Priyadi, A. 2002. Penentuan saat awal pemberian pakan buatan dan hubungannya dengan perkembangan aktivitas enzim pencernaan pada benih ikan baung (Mystus nemurus C.V.). J. Pen. Perik. Indonesia VIII(5): 37-42.

Suryanti, Y., Priyadi, A., \& Subamia, I W. 2006. Penentuan saat pemberian pakan buatan yang tepat berdasarkan perkembangan aktivitas enzim pencernaan pada benih botia (Botia macracantha). Prosiding Seminar Nasional Tahunan III Hasil Penelitian Perikanan dan Kelautan. Yogyakarta, hlm. 306-310.

Tridjoko, Suwirya, K., \& Mahardika, K. 2002. Perkembangan aktivitas enzym trypsin dan saluran pencernaan larva kerapu bebek (Cromileptes altivelis). Laporan Proyek Inventarisasi dan Evaluasi Potensi Sumberdaya Kelautan. Gondol-Bali. Tahun Anggaran 2002, hlm. 86-88. 